\title{
A Method to Develop Critical Thinking: \\ Playing the Devil's Advocate
}

\author{
Sean Eric Kil Patrick Gay Ph.D. \\ School of Policy Studies, Kwansei Gakuin University, Japan \\ (i)/0000-0001-6373-1335
}

DOI: $h t t p s: / / d x . d o i . o r g / 10.46679 / 978819484836310$

\begin{abstract}
The ability to think critically is at the foundation of an equitable and just society. One aspect of critical thinking (CT) is the ability to create and develop structurally sound arguments. Curricular requirements often restrict addressing this issue. Furthermore, students arguing their own opinions often assume agreement and therefore do not see a need to fully explain. As such, I examined how CT can be developed through the use of a timed-writing activity wherein the students argue against their own positions. I employed an action research approach to compare CT development in the intervention class with another class that did not receive the intervention. Analysis of the data suggested that this method was effective, and that encouragement of dissociation has a positive effect on CT development in students.
\end{abstract}

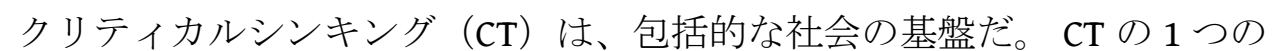
側面は、構造的に正しい議論を作成し開発する能力だ。カリキュラム要 件により、この問題への対処が制限されることがよくある。さらに、自 分の意見を主張する学生はしばしば合意を仮定しているので、説明する 必要はないと思う。このように、研究者は学生が自分の立場に反論する 時限ライティング活動の使用を通してどのように CT が開発されることが できるかを調べた。研究者はこの介入を使用し、介入なしの他のクラス と比較して彼のクラスの CT 発生を比較した。データの分析は、この方法 が効果的であること、そして解離の促進が学生の CT の発達に良い影響を 与えることを示唆した。 
There is an increasingly perceived need for the teaching of critical thinking (CT) in the classroom. The need for CT is fundamentally an ethical issue, and educators are obliged to develop students' critical faculty as part of their duty as educators and citizens (Freire, 1973). This call for empowerment and CT development is not uncommon in the guidelines for course development in many universities in Japan and around the world. In fact, the Japanese Ministry of Education (MEXT) in its "Grand Design for Higher Education toward 2040" has called for the creation of young people who have analytic skills and can bridge classroom learning with realworld issues (2018). Japan's move towards fostering CT as an educational goal is tied with an increased understanding of globalization and the interdependence between Japan and other nations.

The ability to state one's ideas in a meaningful and convincing manner is of growing importance in a society where digitally facilitated micro-social-interactions are the norm. Stylistically, however, there is also a need to focus on the style of argumentation. In fact, argumentation is a central aspect of CT and a necessary $21^{\text {st }}$ Century skill (Asterhan \& Schwarz, 2016). It must also be stated that the ability to formulate complete multi-premise arguments is only a portion of the broader picture; the true benefit of learning argumentation is in the ability to critically analyze the arguments of others.

of particular concern in the development of writing for university students is that several aspects of argumentative writing are non-linguistic. In particular, the inability to form complete multipremise argument structures leads to ineffective student writing (Allagui, 2019). Papers that have single-premise arguments are building the structure of the argument laterally rather than vertically. Papers at this level can only develop a surface-level explanation of phenomena and lack synthesis or evaluation of ideas. Moving beyond the restatement of ideas is essential to develop a cohesive and expressive paper. 


\section{This is a limited preview of the chapter.}

To read the full-text chapter, get access by purchasing this chapter or consider buying the complete book. If your library has subscription to EBSCOhost, the chapter including other chapters of the book can be accessed through your library.

This chapter is a part of the book, 'Development of Innovative Pedagogical Practices for a Modern Learning Experience' ISBN (paperback): 978-81948483-6-3; ISBN (ebook): 978-81-948483-7-0

Book DOI: https://dx.doi.org/10.46679/9788194848363

Available via CSMFL Bookstore, Amazon, Google Play Books, EBSCOhost \& EBSCO eBooks 
meet the needs of modern society, students will need to develop two major aspects of critical thinking: Students will need to have complete multi-premise arguments, but also be able to develop interpersonal communication skills designed to promote meaningful and productive discourse. This research focused on an activity that developed SCT, however, students will also need some support to develop aspects of self-reflection and in tandem, strong interpersonal interactional skills to promote utilization of $\mathrm{CT}$ in collaborative situations.

This study suggests that the devil's advocate writing activity or a permutation thereof, ought to be considered in the development of EFL writing coursework. Students, especially lower-level students such as the participants in this study, are often saddled with repetitive and uninteresting topics. These topics often result in poor writing with a limited demonstration of sound claim structure. The intervention undertaken in this research showed that students could meaningfully support their ideas in a limited period (15 minutes) while developing SCT through writing. Therefore, I recommend that writing topics should not shy away from the controversial but embrace it.

\section{Acknowledgement}

I would like to thank Gretchen Clark for her generous support and input into this project.

\section{References}

Alagozlu, N. (2007). Critical thinking and voice in EFL writing. Asian EFL Journal, 9(3), 118-136.

Allagui, B. (2019). Investigating the quality of argument structure in first-year university writing. In S. Hidri \& S. Hidri (Eds.),English language teaching research in the Middle East and North Africa (pp. 173-196). Palgrave Macmillan. https://doi.org/10.1007/978-3319-98533-6_9

Anderson, L. W., Krathwohl, D. R., Airasian, P. W., Cruikshank, K. A., Mayer, R. E., Pintrich, P. R., Raths, J., \& Wittrock, M. C.(2001). A 
taxonomy for learning, teaching, and assessing: A revision of Bloom's taxonomy of educational objectives. Longman Press.

Asterhan, C. S., \& Schwarz, B. B. (2016). Argumentation for learning: Well-trodden paths and unexplored territories. Educational Psychologist, 51(2), 164-187. https://doi.org/10.1080/00461520.2016.1155458

Baba, K., \& Nitta, R. (2012). Dynamic effects of repeating a timed writing task in two EFL university courses: Multi-element text analysis with Coh-Metrix. In P. M. McCarthy \& C. Boonthum (Eds.), Applied Natural Language Processing: Identification, Investigation and Resolution (pp. 398-413). IGI Global.

Barnawi, O. Z. (2011). Finding a place for critical thinking and self-voice in college English as a foreign language writing classrooms. English Language Teaching, 4(2), 190-197. https://doi.org/10.5539/elt.v4n2p190

Benlahcene, A., Kaur, A., \& Awang-Hashim, R. (2020). Basic psychological needs satisfaction and student engagement: The importance of novelty satisfaction. Journal of Applied Research in Higher Education. https://doi.org/10.1108/JARHE-06-2020-0157

Case, R. (2013).The unfortunate consequences of Bloom's Taxonomy. Social Education, 77(4), 196-200.

Clark, G. (2019). Methods for developing expression of critical thinking in small group discussions. Critical Thinking and Language Learning. 6(1), 1-20.

Cohen, J. (1960). A coefficient of agreement for nominal scales. Educational and Psychological Measurement. 20(1): 37-46. https://doi.org/10.1177\%2F001316446002000104

Cohen, J. (1988). Statistical power analysis for the behavioral sciences Second edition. Lawrence Erlbaum.

Finn, J. D., \& Zimmer, K. S. (2012). Student engagement: What is it? Why does it matter? In S. L. Christenson, A. L. Reschly \& C. Wylie (Eds.), Handbook of research on student engagement(p. 97-131). 
Springer Science + Business Media.

https://doi.org/10.1007/978-1-4614-2018-7_5

Forehand, M. (2005). Bloom's taxonomy: Original and revised. In M.

Orey (Ed.), Emerging perspectives on learning, teaching, and technology.

https://www.d41.org/cms/lib/IL01904672/Centricity/Domain/ 422/BloomsTaxonomy.pdf

Franco, A., Marques Vieira, R., \& Tenreiro-Vieira, C. (2018).Educating for critical thinking in university: The criticality of critical thinking in education and everyday life. ESSACHESS-Journal for Communication Studies, 11(2 (22)), 131-144.

Freire, P. (1973). Education for critical consciousness. Continuum.

Golanics, J. D., \& Nussbaum, E. M. (2008).Enhancing online collaborative argumentation through question elaboration and goal instructions. Journal of Computer Assisted Learning, 24(3), 167180.https://doi.org/10.1111/j.1365-2729.2007.00251.x

Hooks, b. (2010) Teaching critical thinking: practical wisdom. Routledge.

Kanno, Y. (2003). Imagined communities, school visions and the education of bilingual students in Japan. Journal of Language, Identity, and Education, 2(4), 285-300. https://doi.org/10.1207/S15327701JLIE0204_4

Knudson, R. (1992). The development of written argumentation: An analysis and comparison of argumentative writing at four grade levels. Child Study Journal, 22, 167-184.

Krathwohl, D., R. (2002). A revision of Bloom's taxonomy: An overview. Theory into Practice, 41(4), 212-264.

McLaughlin, M., McGrath, D. J., Burian-Fitzgerald, M. A., Lanahan, L., Scotchmer, M., Enyeart, C., \& Salganik, L. (2005). Student content engagement as a construct for the measurement of effective classroom instruction and teacher knowledge. American Institutes for Research. 
MEXT (2018) 2040 Action Plan. Accessed on December 12, 2018 at http://www.mext.go.jp/component/b_menu/shingi/toushin/_ icsFiles/afieldfile/2018/11/26/1411360_3_1.pdf

Norris, S. and Ennis, R. (1989) Evaluating critical thinking. Midwest Publications.

Paul, R. and Elder, L. (2006) The miniature guide to critical thinking: Concepts and tools.https://www.criticalthinking.org/files/Concepts_Tools.pdf Rubin, B. C., Ayala, J., \& Zaal, M. (2017). Authenticity, aims and authority: Navigating youth participatory action research in the classroom. Curriculum Inquiry, 47, 175-194. http://dx.doi.org/10.1080/03626784.2017.1298967

Shehab, H. M., \& Nussbaum, E. M. (2015). Cognitive load of critical thinking strategies. Learning and Instruction, 35, 51-61. https://doi.org/10.1016/j.learninstruc.2014.09.004

Soozandehfar, S., \& Adeli, M. (2016). A critical appraisal of Bloom's Taxonomy. American Research Journal of English and Literature, 2. Stapleton, P. (2001). Assessing critical thinking in the writing of Japanese university students: Insights about assumptions and content familiarity. Written Communication, 18(4), 506548.https://doi.org/10.1177/0741088301018004004

Tan-de Ramos, J. (2010). A study on schema activation, summarizing, and critical evaluation as predictors of writing proficiency. International Journal of Research \& Review, 5(1).

Titsworth, S., Mazer, J. P., Goodboy, A. K., Bolkan, S., \& Myers, S. A. (2015). Two meta-analyses exploring the relationship between teacher clarity and student learning. Communication Education, 64(4), 385-418.

Willingham, D. T. (2008). Critical thinking: Why is it so hard to teach? Arts Education Policy Review, 109(4), 21-32. https://doi.org/10.3200/AEPR.109.4.21-32 


\section{About the author}

Sean Gay is an Associate Lecturer of English at Kwansei Gakuin University in Sanda. He has an MS in TESOL and PhD in Health Services. $\mathrm{He}$ is working to promote a research-based approach to language pedagogy. His research interests include research-based curriculum development, disaster management, CLIL, identity in EFL, and critical thinking in EFL. 
